\title{
Contribution of Fast Food Consumption on Incidence Early Puberty Among Adolescent Girls
}

\author{
Azrimaidaliza $^{1}$, Rauza Sukma Rita ${ }^{2}$, Fitri $\mathrm{Nia}^{3}$ \\ \{azrimaidaliza@ph.unand.ac.id ${ }^{1}$, rauzasukmarita@med.unand.ac.id ${ }^{2}$, fitrinia25@gmail.com ${ }^{3}$ \} \\ Nutrition Department, Andalas University, Padang, West Sumatera, 25127, Indonesia
}

\begin{abstract}
The age at menarche is varied among adolescent girls. Early puberty is at increased risk of a physical and psychosocial problem. The objective of the study was to determine the association of fast food consumption with early puberty among adolescent girls.A cross-sectional design was used to conduct the study with total samples of 159 adolescents girls. Primary data were obtained by interviews using the standardized questionnaires. Statistical analysis was described by univariate and bivariate analysis. The incidence of early puberty was $23,3 \%$ with the average of age at menarche was $12,6 \pm 0,70$ years old. There was a significant association of age at menarche with protein intake (pvalue $=0,0001)$, fat intake ( $p$-value $=0,0001)$ and fast food frequency $(p=0,0001)$. Adolescents girl who consumed fat and protein from fast food more than $30 \%$ and had a frequency of fast food more than 8 times a week with 3-4 types of fast food might be at risk to increase of early puberty. The age at menarche is associated with protein and fat of fast food consumption, besides the role of frequency of fast food. Balanced diet was needed to maintain adolescent girls health.
\end{abstract}

Keywords: Adolescents Girls, Fast Food Consumption, Frequency, Age at Menarche.

\section{Introduction}

Nutritional needs during adolescence are increased because of the increased growth rate and changes in body composition associated with puberty [1]. Early puberty among girls is associated with the risk of anemia in the short term and increasing of the risk of degenerative disease in the long term, including breast, ovarian and endometrial cancers, type 2 diabetes, hypertension and cardiovascular disease [2], also facing the psychosocial problems [3] than average puberty. Based on a national survey in Indonesia year 2010, half of girls teenager have experienced menarche at age 12 years old.

Early puberty was described as early sexual maturation [4]. However, many factors have been proved to be associated with early puberty among adolescent girls, namely nutritional status [5], nutrient intake, hormonal, exposure of mass media and lifestyle, such as fast food consumption [6]. Many factors influence the consumption of fast foods. The ease of availability and purchase is one among them [7].

There was not much data about the dietary pattern which was linked with fast food habits among adolescent girl and early puberty in Western Province in Indonesia. The objective of the study was to determine the association of fast food consumption with early puberty among adolescent girls. 


\section{Methods}

\subsection{Study design}

A cross-sectional study was used to conduct the study among girls at junior high school in two schools (MTsN Model Padang and SMPN 16 Padang) according to a larger amount of the girl's student in Padang. The study was carried out from April until June 2018. The sample was counted by Slovin formula, and a total of 159 girls student participated in this study which chosen by systematic random sampling. The inclusion criteria of the respondent are giving agreement participating in the study by a written consent and exclusion criteria was girls who had already menarche less than age 11 years.

\subsection{Assessment of variables}

A standardized questionnaire examined the age of menarche and history of mother menarche. Food intake was collected by using Semi-Quantitative Food Frequency Questionnaires (SQFFQ). This questionnaire is consist of 240 food items which are usually consumed by people in Indonesia and have been standardized before. To increase the validity of the data, food book which published by Health Ministry of Indonesia was used to remind what respondents consume in a daily. This book is used in dietary surveys in Indonesia.

The fast-food intake, including energy, protein, fat, and carbohydrate intake was categorized of $>30 \%$ Recommended Dietary Allowances or RDA (higher intake) and $\leq 30 \%$ RDA (enough intake), besides categorized frequency of fast food consumption become $>8$ times per week (often) and $\leq 8$ times per week (rarely) based on median (because the data distribution was not normal).A trained interviewer has enrolled the study and had a nutritional education background.

\subsection{Statistical analysis}

Data were processed and analyzed using the Statistical Package for the Social Science(SPSS) Program. Data was presented by mean, standard deviation and percentage. KolmogorovSmirnov test was done to check the normality of numeric data. The association of fast food consumption and age at menarche among adolescent girls were assessed by chi-square test which statistical significance was assumed at a p-value less than 0.05 with $95 \%$ confident interval.

\section{Result}

\subsection{Characteristics and fast food consumption among adolescent girls}

The result showed that almost a quarter of adolescent girls (23.3\%) had aged at menarche less than 12 years or early menarche (mean $\pm \mathrm{SD}=12 \pm 0.7$; minimum $=11$ years; maximum $=13$ years). Based on the history of mother's age at menarche was identified that mothers of the adolescent girl were also had the mean of age at menarche on 12 years with minimum 11 years but maximum aged at menarche was on 15 years. 
The characteristics of the respondents are as shown in Table 1. In this study, the mean of food intake from fast food was $497 \pm 163.34$ calorie for energy intake, $15.72 \mathrm{~g} \pm 5.38$ for protein intake, $17.02 \pm 5.31 \mathrm{~g}$ for fat intake, $65.48 \pm 22.19 \mathrm{~g}$ for carbohydrate intake. The study was also found the mean of the frequency of fast-food consumption was 8 times per week $( \pm 1.97)$.

Table 1. The mean of energy, macronutrient intake and frequency of fast food among adolescent girls

\begin{tabular}{|c|c|c|c|c|c|}
\hline Variables & Mean & Median & $\begin{array}{l}\text { Standard } \\
\text { deviation (SD) }\end{array}$ & Minimum & Maximum \\
\hline $\begin{array}{l}\text { Energy intake of fast food } \\
\text { (calorie) }\end{array}$ & 497.14 & 512,69 & 163.34 & 75.52 & 799.12 \\
\hline Protein intake of fast food $(\mathrm{g})$ & 15.72 & 15,96 & 5.38 & 2.46 & 26.03 \\
\hline Fat intake of fast food $(\mathrm{g})$ & 17.02 & 17.14 & 5.31 & 4.14 & 30.86 \\
\hline $\begin{array}{l}\text { Carbohydrate intake of fast } \\
\text { food }(\mathrm{g})\end{array}$ & 65.48 & 67.00 & 22.19 & 10.30 & 106.12 \\
\hline $\begin{array}{l}\text { Frequency of fast food } \\
\text { consumption (times) }\end{array}$ & 8.26 & 8.00 & 1.97 & 3 & 13 \\
\hline
\end{tabular}

\subsection{Fast food consumption of adolescent girls according to age at menarche}

Table 2 presents the association between fast food consumption and age at menarche among adolescent girls. Overall, the percentage of protein intake of fast food more than $30 \%$ RDA was higher on adolescent girls with early at menarche $(51.5 \%)$ compared to adolescent girls with normal at menarche $(48.5 \%)$. This study showed that protein intake of fast food ( $\mathrm{p}$ value $=0.0001)$, fat intake of fast food $(\mathrm{p}$-value $=0.0001)$ and frequency of fast food consumption ( $\mathrm{p}$-value $=0.0001$ ) were significantly associated with age at menarche among adolescent girls in junior high school.

Table 2. The association of food intake and age at menarche among adolescent girls

\begin{tabular}{|c|c|c|c|c|}
\hline \multirow{3}{*}{ Variables } & \multirow{3}{*}{ Categories } & \multicolumn{2}{|c|}{ Age at menarche } & \multirow{3}{*}{ p-value } \\
\hline & & Early & Normal & \\
\hline & & $\mathrm{n}(\%)$ & $\mathrm{n}(\%)$ & \\
\hline \multirow{4}{*}{$\begin{array}{l}\text { Energy intake of fast food } \\
\text { (calorie) } \\
\text { Protein intake of fast food }(\mathrm{g})\end{array}$} & $>30 \%$ RDA & $17(32.1)$ & $36(67.9)$ & \multirow[t]{2}{*}{0,097} \\
\hline & $\leq 30 \%$ RDA & 20 (18.9) & $86(81.1)$ & \\
\hline & $>30 \% \mathrm{RDA}$ & $17(51.5)$ & $16(48.5)$ & \multirow[t]{2}{*}{$0.0001 *$} \\
\hline & $\leq 30 \% \mathrm{RDA}$ & $20(15.9)$ & $106(84.1)$ & \\
\hline \multirow[t]{2}{*}{ Fat intake of fast food $(\mathrm{g})$} & $>30 \% \mathrm{RDA}$ & $16(48.5)$ & $17(51.5)$ & \multirow[t]{2}{*}{$0.0001 *$} \\
\hline & $\leq 30 \% \mathrm{RDA}$ & $21(16.7)$ & $105(83.3)$ & \\
\hline \multirow{2}{*}{$\begin{array}{l}\text { Carbohydrate intake of fast } \\
\text { food }(\mathrm{g})\end{array}$} & $>30 \% \mathrm{RDA}$ & $16(29.6)$ & $38(70.4)$ & \multirow[t]{2}{*}{0.245} \\
\hline & $\leq 30 \% \mathrm{RDA}$ & $21(20.0)$ & $84(80.0)$ & \\
\hline \multirow{2}{*}{$\begin{array}{l}\text { Frequency of fast food } \\
\text { consumption (times per week) }\end{array}$} & $>8$ & $31(44.3)$ & $39(55.7)$ & \multirow[t]{2}{*}{$0.0001 *$} \\
\hline & $\leq 8$ & $6(6.7)$ & $83(93.3)$ & \\
\hline
\end{tabular}

*statistically significant

The result also found that more frequent of fast food consumption, namely more than 10 times a week were significantly higher percentage of being early menarche than normal menarche among adolescent girls. 


\section{Discussion}

The study identified that majority of school girls had puberty for the first time between 12 until 14 years with the mean of age at menarche 12 years. This finding was similar to a national survey in Indonesia year 1995 [8], and it was categorized into normal menarche. However, the percentage of incidence of early puberty among junior school children was higher than the percentage of incidence of early puberty in the Indonesian Basic health survey in the year 2010 $(22.0 \%)$. Then, the mean of age at menarche of $12.60 \pm 0.7$ years in this study was lower than 13.66 \pm 1.87 years which reported by Evans Paul Kwame Ameade in 2016[9] and higher than $11.2 \pm 0.33$ years by Yvonne Kelly, et al. studied in 2017[10].

More than half respondents $(67.9 \%)$ was in enough categorized on energy intake of fast food according to recommended dietary allowance among normal menarche category. Higher consumption of fast food might increase the amount of energy intake. It is recommended for young age not to consume fast food above $30 \%$ of energy needs based on recommended dietary allowance. The mean energy intake of fast food in this study was 497 calorie which means this number was below the recommendation in Indonesia.

The study found that percentage high protein intake of fast food $(51.5 \%)$ among school girls was a little higher than the percentage of enough protein intake of fast food $(48.5 \%)$ on early menarche, but the percentage of fat and carbohydrate intake was higher on enough category among normal menarche of respondents. However, the mean protein intake of fast food $(15.72 \mathrm{~g})$ was below of the recommendation. The similar result was identified on the mean of fat intake of fast food (17.02 g) and the mean of carbohydrate of fast food (65.48 g) which mean the adolescent girls consumed fast food corresponding to recommended dietary allowances or below than $30 \%$.

The study stated that more than half of school girls consumed fast food less than 8 times per week $(55.7 \%)$ on normal menarche category. The more frequent of fast-food consumption was higher the risk of early puberty incidence among adolescent girls. Respondents were more frequent consuming fried chicken than other food, namely spaghetti, french fries, hamburger, and pizza.

From the bivariate analysis using chi-square test was found that protein intake of fast food, fat intake of fast food and frequency of fast food consumption were determinant of early menarche among adolescent girls in junior high school ( $p$ value $<0.05$ ). The study also showed that fried chicken had a higher contribution to the source of protein and fat intake of fast food. Abdulmoein E. Al-agha supported these findings in 2014 which observed that age at menarche was significantly correlated with chicken consumption. This study was consistent with the fact of increasing consumption of animal protein, such as chicken and beef have a significant association with early puberty [6].

\section{Conclusion}

The study identified that the mean of age at menarche was $12.60 \pm 0.7$ years among girls in the junior high school and it was founded $23.3 \%$ of girls had experienced menarche at an age below 12 years. Overall, the majority of young girls consume fast food based on their needs. The result found that protein intake of fast food, fat intake of fast food and frequency of fast food consumption had a contribution to the early puberty among adolescent girls. We suggest 
to the young girls to having a healthy food habit or consuming a balanced diet according to get normal menarche.

Acknowledgments. The authors thank the Dean of the Public Health Faculty University of Andalas in West Sumatera Province, Indonesia in supporting the license of collecting data and all the respondents who participated in this study.

\section{References}

[1] Kumari K. A study on eating habits and food attitude of adolescent girls of Patna (Bihar). Food Sci Res J [Internet]. $2014 ; 5$ (1): 47-50. Available from: http://www.researchjournal.co.in/online/FSRJ.html

[2] Canoy D, Beral V, Balkwill A, Wright FL, Kroll ME, Reeves GK, et al. Age at menarche and risks of coronary heart and other vascular diseases in a large UK cohort. Circulation. 2015;131(3):237-44.

[3] Lien L, Haavet OR, Dalgard F. Do mental health and behavioural problems of early menarche persist into late adolescence? A three-year follow-up study among adolescent girls in Oslo, Norway. Soc Sci Med. 2010;71(3):529-33.

[4] Yoo JH. Effects of early menarche on physical and psychosocial health problems in adolescent girls and adult women. Vol. 59, Korean Journal of Pediatrics. 2016. p. 357-63.

[5] Karapanou O, Papadimitriou A. Determinants of menarche. Reprod Biol Endocrinol. 2010;8.

[6] [Al Agha AE. Correlation between Nutrition and Early Puberty in Girls Living in Jeddah, Saudi Arabia. J Womens Heal Care. 2015;4(3).

[7] Lattimer JM, Haub MD. Effects of dietary fiber and its components on metabolic health. Vol. 2, Nutrients. 2010. p. 1266-89.

[8] Batubara JRL, Soesanti F, van de Waal HD. Age at menarche in Indonesian girls: a national survey. Acta Med Indones. 2010;42(2):78-81.

[9] Ameade EPK, Garti HA. Age at menarche and factors that influence it: A study among female university students in Tamale, Northern Ghana. PLoS One. 2016;11(5).

[10] Kelly Y, Zilanawala A, Sacker A, Hiatt R, Viner R. Early puberty in 11-year-old girls: Millennium Cohort Study findings. Arch Dis Child. 2017;102(3):232-7. 